\title{
Practical Difficulties and Countermeasures of Small Credit for Poverty Alleviation Policy Based on the Perspective of Inclusive Finance
}

\author{
Xiaowei Zhou*, Qi Wang \\ International Business School, Shaanxi Normal University \\ Xi'an 710119, Shaanxi \\ Email:wqhhu1604@snnu.edu.cn
}

\begin{abstract}
Financial poverty alleviation is one of the important ways of targeted poverty alleviation. Small credit for poverty alleviation is a financial product tailored for the poor in China. It is also the most direct embodiment of the general financial concept. However, there is still a certain gap between the policy of microfinance credit and the concept of Inclusive Finance. In view of the problems in the implementation of the policy, the paper puts forward some suggestions for improving the small credit support, such as maintaining the sustainability of financial service, strengthening the construction of rule of law of rural finance, strengthening the credit management of farmers. The utilization efficiency of small credit promotes the inclusive financial system in China.
\end{abstract}

Keywords-Financial poverty alleviation; Small credit for poverty alleviation; Poor households; Inclusive finance

\section{INTRODUCTION}

Financial industry is playing an increasingly important role in modern economy. The healthy and rapid development of the economy is inseparable from the highly developed financial industry. The economic development of poor areas in China has been lagging behind for a long time. In rural areas, the financial infrastructure is scarce, the number of financial institutions and organizations is small, and the quality of service is low; the rural residents lack the mortgaged assets as well as the credit information needed to obtain financial services, and do not have the knowledge and ability to make full use of financial resources. The uneven distribution of objective financial resources and the limitations of the poor themselves become a serious obstacle to poverty alleviation. Therefore, in order to realize the overall poverty alleviation and sustainable development of the poverty-stricken population, we must make up for the short board of finance.

The concept of Inclusive Finance was first proposed by the United Nations in 2005, with the meaning of providing a sustainable way to provide appropriate and effective financial services for groups with financial needs at a reasonable cost. Since the concept was put forward, government and academia in China have attached great importance to it, and the development of Inclusive Finance has become a common understanding. Then the establishment of such financial institutions which serves small and medium sized enterprises and low-income people as small loan companies, village banks, rural cooperative banks and so on, and actively promote the reform of financial institutions in order to improve their service to the vulnerable groups.

Financial poverty alleviation is an important way to tackle poverty in China. It is also a concrete practice of inclusive financial philosophy. Since the implementation of the precision poverty alleviation program, more financial institutions have participated in the practice of precision poverty alleviation. Financial innovation in the field of poverty alleviation has emerged endlessly, financial products are increasingly rich, and financial poverty alleviation has promoted the process of poverty reduction to a large extent. The inclusive financial system is becoming more and more perfect in the process of financial poverty alleviation. The financial needs of the disadvantaged people, with the poor population as the main body, can be met in more ways and lower costs, and more of the poor people are included in the formal financial system. Small credit poverty alleviation credit, which is the most important way to bring poor households into the formal financial system, is the most important way to bring poor households into the formal financial system. It is also a financial product that can benefit the poor and reflect the financial benefits directly.

The problem is that small credit, as a means of poverty alleviation, are not like ordinary financial services which are provided by a financial institution with the goal of pursuing profits. The government's administrative means are also involved in it. In the concrete practice, the problem is reflected the low utilization efficiency of the financial resources and the endless use of all kinds of irrational use. This paper, taking the small poverty alleviation credit as the research object of the financial poverty alleviation policy, first points out the various unreasonable phenomena in the process of the implementation of the policy, and analyzes the causes of these phenomena. Finally, based on the universal financial concept and the successful experience of the world, the paper puts forward the improvement of the financial poverty alleviation work. 


\section{PRACTICAL DIFFICULTIES AND CAUSES OF SMALL CREDIT POLICY FOR POVERTY ALLEVIATION}

The poverty reduction effect of microfinance has been tested by the practice of the international community. Successful practices include Bangladesh Rural Bank in Bangladesh, Action International in Latin America and Women's Association of self starting businesses in India.(Du Xiaoshan, 2015).The success of microcredit to help the poor get out of poverty shows that the financial system can achieve sustainable development by enhancing its inclusiveness and universality to drive more poor people to overcome poverty. On the basis of learning from the successful experience of the world, Hainan province has also carried out beneficial exploration in the field of microfinance, and has made good achievements and accumulated some experience. The successful cases of microfinance at home and abroad provide a new idea for our country's poverty alleviation. Microfinance credit is a special financial aid product specially designed for the poor households who were set up archives. The product design is different from the ordinary microfinance. The main points of the policy are "below 50 thousand yuan, less than 3 years, no guarantee, no mortgage, lending at the benchmark interest rate, financial discount, and risk compensation for county construction" It implies the exclusiveness and special benefits of credit resources.

The small credit policy for poverty alleviation has to be the gospel of poor households, giving them the opportunity to get the capital base of poverty relief at very low cost. However, judging from the effect of policy implementation, the policy is still far from the expected target. Not only does the poverty alleviation function be limited, but it also leads to the waste of credit resources, and it may be described as a strange cluster. Although partial poverty applied for loans, it did not invest in production as the government wanted, but to improve their current consumption, rebuild and expand their homes, increase their daily consumption expenditure, and even a few use the aid of poor loans for entertainment and showy consumption. These phenomena can be explained by the following reasons.

(1) The loans of poor households are mainly based on family loans, and the borrowing from formal financial institutions is not easy to be widely accepted. Almost all the poor people living in our country live in the countryside. There are some differences between the system and custom of the rural society and the modern market economy. In the specific system and customs, the behavior of the farmers' borrowing and lending has its own unique features. Zhang Jie (2005) believes that the rural society in China is a "circle structure" composed of different levels of "circle", which determines the loan of farmers to a certain extent by friendship and lending. At the same time, the financial aid and financial system of the formal financial institutions are excluded from the circle. So if they have the demand for lending, they are more likely to resort to relatives and friends rather than to seek services from regular financial institutions. This is the common pattern of behavior of poor households. So when small poverty alleviation credit appears in their lives, it is still difficult to ensure that they all have the enthusiasm to change their inherent ideas and to borrow from the regular financial institutions.
(2) The non-productive borrowings of poor households. There are many studies on the demand structure of Chinese farmers' borrowing, but there is a more consistent conclusion that farmers' borrowing mainly stems from non-productive demand. As the extreme lack of wealth and the difficult survival of the poor, their capital gap is first derived from the shortage of basic living consumption and such major family events as marriage and funeral. There is also an indirect reason for the non-productive nature of the loan of poor households, that is, the high risk and low yield of productive investment. The poor economic base of poor areas, poor human capital of households, natural disasters, market fluctuations and other risks and uncertainties implies that the yield of the production and investment of the poor households is not easy to meet the feasibility of investment. The unfavorable investment environment means that even with a favorable loan as a capital investment, the risk-averse poor households will still not invest in high risk production projects, and the low cost credit resources may be the way for them to temporarily alleviate the predicament of survival and improve the consumption of the current period.

(3) The inappropriate incentive has led to the irrational use of financial resources. Financial resources are also a scarce economic resource. The use of scarce resources will inevitably lead to competition, which means that we must pay for the scarce resources. (Zhang Wuchang, 2010, p85-91). The price of credit funds is interest and the transaction cost of signing the loan contract. "No mortgage, no guarantee" to a large extent reduced the transaction costs of poor households; "financial discount" means that the poor will not pay interest within the period stipulated in the contract. These two policy stipulates that the cost of obtaining credit resources for poor households will be greatly reduced, and the demand for loans will also increase correspondingly. The characteristics of the scattered distribution of the poor households and the lack of the personnel of the agricultural financial institutions have led to the inability to supervise the use of loans by the borrowers. In the absence of supervision, poor households will naturally use loans according to their own needs and wishes, so there will be a large number of poverty alleviation credit resources, which are not used to develop production projects that can drive poor households out of poverty according to the policy requirements, but are the most urgent for them to build houses and major family events. On demand, there is even more for luxury and entertainment consumption. 
III. POLICY RECOMMENDATIONS FOR IMPROVING CHINA'S FINANCIAL POVERTY ALLEVIATION FROM THE PERSPECTIVE OF INCLUSIVE FINANCE

The misuse of micro-credit and the low efficiency of poverty alleviation have caused a negative impact on the society, and have aroused the attention of the government. Strict regulations have imposed on the Small Credit Funds. In fact, this is the phenomenon of irrational use of credit resources in the absence of the price mechanism. Experience would teach that administrative regulations may lead the use of scarce resources astray. Therefore, to give full play to the effectiveness of the poverty alleviation of microfinance, we should give up the short-term behavior, adhere to the principle of Inclusive Finance and establish a long-term mechanism that follows the law of the market and helps to promote the improvement of the rural formal financial system.

(1) Maintain the sustainability of poor-oriented finance service. From the perspective of the financial institutions (banks), the law of following the market is maintained in the poverty-stricken areas. A key aspect of the continued operation is the sustainability of the financial institutions. The design of credit products such as Grameen Bank in Bangladesh, the Compartamos Bank of Mexico and the people's Bank of Indonesia, are the core aspects of the Pratt and whiten finance. If the financial institutions can not provide durable services for the poor, the support of the government in the short term is difficult to sustain even in the short term. This will lead to the shortage of financial supply in the poverty-stricken areas, and the financial services needed for the development of the poor population are difficult to be met. There may be a return to poverty.

(2) Strengthen the construction of the rule-of-law in rural finance. Good rule-of-law is an important guarantee for effective implementation of financial aid for the poor. The Mexico government has promoted the reform of the legal system of the bank, and provided a strong guarantee for the success of the construction of the inclusive financial system and the successful implementation of financial poverty alleviation for the legalization of the financial organizations serving the poor. In China, a considerable number of financial organizations and lending methods, such as microfinance companies, mutual funds, have a considerable number of loans for farmers. It has been a great convenience. However, these financial organizations and their lending behavior have not been recognized and guaranteed by law, resulting in these financial organizations unwilling to lend money to poor people. We should set up a perfect legal system to bring these financial organizations into the framework of the legal system, protect their rights by law, and also better supervise and restrain the behavior of these financial organizations. This is beneficial to the improvement of the pluralistic inclusive financial system in the rural financial market, and the poor population and so on.

(3) Strengthen credit management. Good credit is the necessary condition for poor households to obtain credit, and also an important way to cultivate their ability to adapt to the loan market. Credit management capability is an important condition for ensuring the sustainable operation of financial institutions. The People's Bank of Indonesia and the Bank of Mexico, which have been successful in microfinance, have a good and unique credit management system. The agent system of the people's Bank of Indonesia is an effective way to obtain customer credit. In addition, they have incentive schemes for good credit clients (Zhou Mengliang, Peng Yating, 2015). In China, credit management of financial institutions, such as rural credit cooperatives, agricultural firms and other financial institutions providing financial services to rural areas, is mainly based on customer's deposit and loan information. Huang Yiping (2017) believes that the social strategy based on customer personality and social relations is conducive to improving the credit management level of financial institutions. In addition, the rising of big data and cloud computing is also an effective way to improve the credit management of financial institutions.

\section{REFERENCES}

[1] Du X S, Sun T Q, et al. Inclusive financial theory and policy.

[2] Zhang J. Peasant household, state and China's agricultural loan system: a long-term perspective, [J], Financial research, 2005, (02).

[3] Zhang W C. Economic Explanation,[M], Published by Citic,the Chinese version.

[4] Zhou M L, Peng Y T,. Theory of Financial Poverty Alleviation in China-Based on Inclusive Finance, $[\mathrm{J}]$. Reformation\&Strategy. 2015,(12).

[5] Huang Y P, Fu Q Z,. The direction of rural financial supply side reform,[J], Tsinghua Financical Review,2017,(07) 